\title{
IGCP 272 - LATE PALAEOZOIC AND EARLY MESOZOIC CIRCUM- PACIFIC EVENTS AND THEIR GLOBAL CORRELATION
}

DICKINS, J. M., Bureau of Mineral Resources, P.O. Box 378, Canberra, A.C.T. 2601, Australia

IGCP 203 - Permo-Triassic events of eastern Tethys and their intercontinental correlation - focussed on the Permian-Triassic boundary sequences and in particular there was a consensus that the distinctive biological changes were associated with strong sea-level and tectonic change, strong volcanic activity and a harsh climate. These factors were connected with an important change in the environment and with the exception perhaps of the climate, reflected deep-seated changes within the earth. The project also resulted in improving the physical understanding of the sequences and their biostratigraphy and correlation.

IGCP 272 was developed, and was approved in 1988, to apply these results to understanding the Late Palaeozoic and Early Mesozoic and was focussed on the Pacific as integration around this region seemed to offer especially fruitful possibilities.

Working group meetings up to the end of 1991 have been held in Australia (Newcastle and Hobart), New Zealand (Dunedin), South America (Sao Paulo and Buenos Aires) and North America (Washington). Meetings are planned in North America, Japan, Eastern Siberia or Thailand and western Europe (France-Spain-Austria).

Special cooperation has developed with the Carboniferous, Permian and Triassic Subcommissions of IUGS and with IGCP 214 - Global Bio-events. Using the more exact time correlations developed it has now been possible to show that major geological and biological events (of different levels of significance) are associated with major boundaries already recognized in the World Standard Stratigraphical Time Scale. These comprise the CarboniferousPermian, the mid-Permian (twofold subdivision, the Permian-Triassic (already recognized in earlier work), the Lower-Middle and Middle-Upper Triassic and the Triassic-Jurassic boundaries.

A special achievement of the project has been to show the similar significance of the Midian-Dzhulfian boundary within the Upper Permian but corresponding closely to the traditional Lower-Upper Permian of China and the Middle-Upper Permian of Japan.

Although there are also other events at levels which have not been investigated by the project, those outlined all seem to reflect important changes within the earth. 